\title{
Nucleic acid detection in the diagnosis and prevention of schistosomiasis
}

\author{
Ping He ${ }^{1,2,3}$, Lan-gui Song ${ }^{1,2}$, Hui Xie ${ }^{1,2}$, Jin-yi Liang ${ }^{1,2}$, Dong-ya Yuan ${ }^{3}$, Zhong-dao Wu ${ }^{1,2^{*}}$ and Zhi-yue Lv $v^{1,2^{*}}$
}

\begin{abstract}
Schistosomiasis is an important zoonotic parasitic disease that causes serious harms to humans and animals. Surveillance and diagnosis play key roles in schistosomiasis control, however, current techniques for surveillance and diagnosis of the disease have limitations. As genome data for parasites are increasing, novel techniques for detection incorporating nucleotide sequences are receiving widespread attention. These sensitive, specific, and rapid detection methods are particularly important in the diagnosis of low-grade and early infections, and may prove to have clinical significance. This paper reviews the progress of nucleic acid detection in the diagnosis and prevention of schistosomiasis, including such aspects as the selection of target genes, and development and application of nucleic acid detection methods.
\end{abstract}

Keywords: Schistosoma japonicum, S. mansoni, S. haematobium, Diagnosis, Nucleic acid detection

\section{Multilingual abstracts}

Please see Additional file 1 for translations of the abstract into the six official working languages of the United Nations.

\section{Introduction}

Schistosomiasis or bilharzia, a serious parasitic disease (third in importance to malaria and amoebiasis) caused by blood flukes, continues to plague many developing countries in the tropics. According to the World Health Organization (WHO) [1], in 2012 there were still 240 million patients with schistosomiasis globally, of which $45.8 \%$ were children aged between 5 and 14 years, with $93 \%$ of patients living in Africa. These statistics show little change from those reported previously [2, 3], indicating that schistosomiasis has not yet been effectively controlled.

Human schistosomiasis is mainly caused by three species of schistosomes: Schistosoma japonicum, S. mansoni, and S. haematobium. A schistosome has a complex life cycle. The adult worms parasitize in the host's blood system, and their eggs are excreted through human feces

\footnotetext{
* Correspondence: wuzhd@mail.sysu.edu.cn; Ivzhiyue@mail.sysu.edu.cn ${ }^{1}$ Department of Parasitology, Zhongshan School of Medicine, Sun Yat-sen University, Guangzhou 510080, China

${ }^{2}$ Key Laboratory of Tropical Disease Control, Ministry of Education, Guangzhou 510080, China

Full list of author information is available at the end of the article
}

or urine. Then, the eggs hatch into miracidia in freshwater sources and quickly penetrate into intermediate host snails, which can subsequently become sporocysts and develop into cercaria by asexual reproduction. Humans acquire the infection after direct contact with cercaria released from infected snails. Different species of schistosomes share similar epidemic patterns.

Accurate surveillance and diagnosis play key roles in the prevention and control of schistosomiasis. Firstly, information on snail infection and cercariae distribution is required in order to evaluate the risk of infection. Both cercarial shedding and microscopic examination of snails are conventional diagnosis methods. However, the positive rate of snails achieved using etiological methods significantly decreases in endemic areas [4]. Moreover, an etiological method is unable to distinguish between the different species of cercaria. The Kato-Katz technique is still the gold standard in schistosomiasis diagnosis. This technique is cheap, convenient, and qualitative [5], but is limited in the diagnosis of low-grade and prepatent infections, as well as in evaluating drug therapeutic effects. The vast increase in genome data for parasites offer valuable insights into the development of novel drug candidates and more accurate diagnostic tools [6]. Some researchers have reported that certain nucleic acid sequences derived from schistosomes can be detected in human sera $[7,8]$, suggesting that nucleic acid detection 
may have equivalent diagnostic value as direct parasite detection. Accordingly, the detection of nucleic acid is becoming one of the research foci in the diagnosis of schistosomiasis. Different nucleic acid detection methods have been developed, permitting accurate detection using various samples: infective snails tissue [9-14], cercaria in contaminated water $[15,16]$, and excretion and blood sample from humans [17-23] and animals [7, 24-27].

Furthermore, nucleic acid-based detection has been shown to be superior in identifying different schistosomes in cases of low-grade infections. The rate of positivity is dramatically higher than that when using the Kato-Katz method and miracidium hatching $[8,12,18,28-30]$. Deoxyribonucleic acid (DNA)-based assays remarkably reduce the false-negative rate and effectively monitor potential exposure to schistosomiasis. Although immunological methods have comparable sensitivity and specificity as the polymerase chain reaction (PCR) technique, immunological methods cannot distinguish between current infections and past infections [24], which may lead to inappropriate treatment intervention. In contrast, PCR can not only precisely evaluate drug therapeutic effects $[7,27,31-33]$, but can also identify early infections $[7,9-11,25,34-36]$ and assess infection density in hosts [37].

This paper reviews the various methods of nucleic acid detection and their sensitivities and specificities in the diagnosis of schistosomiasis.

\section{Review}

\section{Target sequences of nucleic acid derived from} schistosomes

'Target sequence' refers to a candidate DNA sequence in a polymerase chain reaction. An applicable target sequence is required for the development of PCR methods. Firstly, the sequence must be species-specific and highly conserved to guarantee the method's specificity and avoid false-positive results. Secondly, the sequence should contain considerable copies. A greater abundance of the target gene improves the detection limit, enabling detection of trace amounts in a sample and decreasing the false-negative rate. Currently, there are several different target genes used in nucleic acid detection. These are summarized in Table 1.

\section{Repetitive sequences}

Repetitive sequences are highly repetitive DNA sequences located in a chromosom. An example is SjR2 [GenBank accession no: AF412221], a non-long terminal repeat retrotransposon first isolated from $S$. japonicum genome by Laha [38]. Hybridization analyses have indicated that SjR2 were dispersed throughout S. japonicum chromosomes. SjR2 is about $3.9 \mathrm{~kb}$ in length with a high copy number (about 10,000 copies per cell), accounting for up to $14 \%$ of the nuclear genome. Various Chinese researchers have characterized this sequence using various methods: PCR [24], real-time fluorescent quantitative PCR [37], loop-mediated isothermal amplification (LAMP) [7], and nested PCR assay [39]. Results showed that no specific amplification occurred in S. mansoni [24], Paragonimus westermani, Clonorchis sinensis, or Trichinella spiralis [37]. Thus, $\mathrm{SjR} 2$ is an ideal target sequence for $S$. japonicum nucleic acid detection. Similarly, a new 303 bp sequence from another repeat retrotransposon (SjCHGCS19) also showed high sensitivity and specificity to $S$. japonicum. A nested PCR technique based on SjCHGCS19 was developed and successfully applied to detect serum samples from rabbits and human patients [40].

SM1-7 [GenBank accession no: M61098] is a highly repeated, tandemly arranged DNA sequence from $S$. mansoni, which contains 121 bp tandem repeats (600,000 copies per cell) and comprises at least $12 \%$ of $S$. mansoni genome of both sexes [41]. Based on this sequence, PCR [22], real-time PCR [26], LAMP [10], and touchdown PCR [42] methods have been established. Sensitivity tests have shown that there is no cross-reaction with S. haematobium, S. magrebowiei [41], Ascaris lumbricoides, Ancylostoma duodenale, Taenia solium, Trichuris trichiura [22], S. intercalatum, Trichobilharzia ocellata, Apatemon minor, Diplostomum spathaceum, Echinostoma caproni, E. revolutum, Hypoderaeum conoideum, and Isthmiophora melis. However, a cross-reaction was observed with $S$. rodhaini [15]. Hence, the SM1-7 sequence is an ideal target gene of S. mansoni.

Dra I [GenBank accession no: DQ157698] is a tandem repeat sequence of $S$. haematobium genomes. It is also $121 \mathrm{bp}$ in length and contains a $\operatorname{Sau} 3 \mathrm{~A}$ restriction site, accounting for $15 \%$ of the entire genome. It was first obtained by Hamburger using a PCR method [43]. Studies confirmed that this approach enabled the detection of single cercaria, indicating that it's a potential tool for the detection of schistosomeinfected water sources. A specificity study found that Dra I does not hybridize with S. mansoni, T. ocellata, and Echinostoma spp., but can hybridize with S. mattheei, S. magrebowiei, S. bovis, S. curassoni, and S. intercalatum. To overcome the poor specificity of Dra I, a combined detection methodology, based on Dra I and the repetitive sequence SH73 [44], has been established, which can accurately discriminate between the trematodes mentioned above. Additionally, PCR [43], real-time PCR [23], and LAMP [10] targeted at Dra I have been developed and applied to detect excrement and serum DNA from humans and snails, indicating its potential application in the diagnosis of schistosomiasis. 
Table 1 Target sequences used for detecting schistosomiasis in humans

\begin{tabular}{|c|c|c|c|c|}
\hline Target sequences & Method ${ }^{[R e f]}$ & Detection limit & Sensitivity \% & Specificity $\%$ \\
\hline \multicolumn{5}{|l|}{ Repetitive sequences } \\
\hline SjCHGCS19 & Nested PCR [41] & 2.02 copies & 97.67 & 96.07 \\
\hline \multirow[t]{4}{*}{ SjR2 (AF412221) } & PCR [24] & $0.8 \mathrm{pg}$ & 60 & 100 \\
\hline & Real-time PCR [38] & 44.7 copies & - & - \\
\hline & LAMP [7] & $0.08 \mathrm{fg}$ & 96.7 & 100 \\
\hline & Nested PCR [40] & - & - & - \\
\hline \multirow[t]{4}{*}{ SM1-7 (M61098) } & PCR $[22,67]$ & $1 \mathrm{fg}$ & 96.7 & 88 \\
\hline & Real-time PCR [26] & 0.02 egg & - & - \\
\hline & LAMP [10] & $0.1 \mathrm{fg}$ & - & - \\
\hline & Touchdown PCR [43] & $10 \mathrm{fg}$ & - & - \\
\hline \multirow[t]{3}{*}{ Dra I (DQ157698) } & PCR [44] & $10 \mathrm{fg}$ & - & - \\
\hline & Real-time PCR [23] & 0.5 EPG & - & - \\
\hline & LAMP [10] & $0.1 \mathrm{fg}$ & - & - \\
\hline \multicolumn{5}{|l|}{ Ribosomal DNA } \\
\hline \multirow[t]{3}{*}{$18 \mathrm{~s} r \mathrm{rDA}$} & Nested PCR [46] & $10 \mathrm{fg}$ & - & - \\
\hline & PCR [47] & $40 \mathrm{pg} / \mathrm{ul}$ & - & - \\
\hline & Real-time PCR [25] & $0.01 \mathrm{pg}$ & - & - \\
\hline \multirow[t]{3}{*}{$28 \mathrm{~s} r \mathrm{rDN}$} & Multiplex PCR [48] & - & 94.4 & 99.9 \\
\hline & PCR [49] & - & - & - \\
\hline & LAMP [9] & $100 \mathrm{fg}$ & - & - \\
\hline SSU-rDNA (X53047) & Real-time PCR [50] & $10 \mathrm{fg}$ & - & - \\
\hline \multicolumn{5}{|l|}{ Mitochondrial DNA } \\
\hline NADH I & Real-time PCR [51] & $1 \mathrm{EPG}$ & - & - \\
\hline NADH-3 & PCR [55] & $1 \mathrm{pg}$ & - & - \\
\hline $\operatorname{cox} I$ & PCR [56] & $0.01 \mathrm{pg}$ & - & - \\
\hline
\end{tabular}

EPG eggs per gram of feces

"-": no mention or no accurate data in paper

\section{Ribosomal DNA}

The ribosomal DNA (rDNA) sequence is highly repetitive and conserved, and enables the encoding of ribosomal RNA (rRNA). The $18 \mathrm{~S}$ and $28 \mathrm{~S}$ subunits have been applied in the detection of nucleic acid sequences of schistosomes. As early as in 1997, a nested PCR technique based on 18 s rDNA was developed and successfully used to detect a single sporocyst just 1 day after infection with S. mansoni [45]. The detection limit has been shown to be $10 \mathrm{fg}$. This approach can effectively monitor infected snails. Using the $18 \mathrm{~s}$ rDNA of S. japonicum, a simple and rapid PCR assay was developed and applied to identify infected Oncomelania hupensis snails [46]. Similarly, a real-time PCR technique also based on 18 s rDNA gene of S. japonicum was established and used to detect parasite-derived DNA in mouse feces and serum samples [25]. The detection limit was $10 \mathrm{fg}$, which is 100 times more sensitive than that arrived at using conventional PCR. No cross-reaction was found with $S$. mansoni, C. sinensis, and P. westermani; the exception was $S$. sinensium. However, this target sequence shows high similarity with $S$. malayensis, S. mekongi, and $S$. sinensium using alignment software, which indicates that this method is potential tool both for monitoring infection with Asian schistosomes and for early diagnosis of schistosomiasis. Additionally, a powerful multiplex PCR technique based on 28 s rDNA of several schistosomes has been developed and applied in the detection of schistosomiasis using human urine specimens [47]. The sensitivity and specificity is up to $94.9-100 \%$ and 98.9-99.9\%, respectively. Meanwhile, a PCR assay, also based on $28 \mathrm{~s}$ rDNA, has been established and successfully used to detect nucleic acid in mice feces [48]. In another study, a real-time PCR method based on the small subunit (SSU) rDNA [GenBank accession no: X53047] was established and able to detect as little as $10 \mathrm{fg}$ of feces [49]. No cross-reaction was found with E. paraensis, S. haematobium, S. japonicum, S. rhodaini, 
Cercaria minensis, C. macrogranulosa, and C. caratinguensis, indicating satisfactory specificity and sensitivity. Using the $28 \mathrm{~s}$ rDNA sequence [GenBank accession no: Z46504] of S. japonicum, PCR and LAMP methods were able to detect 362 snails in endemic areas, showing these methods' potential for monitoring infected water sources [9]. In 2015, a LAMP assay successfully detected Oncomelania hupensis snails collected from 28 endemic areas, demonstrating no cross-reaction with P. westermani, C. sinensis, S. mansoni, and Angiostrongylus cantonensis [50].

\section{Mitochondrial DNA}

Mitochondrial DNA is a circular DNA molecule that exists in eukaryotic cells. It is highly conserved and repetitive (thousands of copies per cell), which means it is also an ideal target sequence. A novel real-time PCR technique targeted at nicotinamide adenine dinucleotide hydrogen (NADH) I (mitochondrial NADH dehydrogenase I gene) was developed [51], which was specific for S. japonicum when tested against S. mansoni, S. haematobium, S. bovis, T. trichiura, A. duodenale, and Taenia spp.. This method was successfully applied to detect $S$. japonicum DNA in human stool samples $[28,52,53]$ with low-intensity infections, and in pig feces [54]. Recently, a specific and efficient PCR assay based on NADH-3 [GenBank accession no: KF834975] was described and successfully used to detect snails and urine samples of patients infected with schistosome [55]. This approach can accurately differentiate $S$. haematobium from S. bovis, S. mattheei, S. curassoni, S. intercalatum, and S. magrebowiei, indicating a potential application in the identification of a coinfection.

COX I is a mitochondrial gene encoding cytochrome C oxidase subunit I. A powerful PCR assay targeted at COX I of several human schistosomes was developed, which was able to identify and differentiate $S$. mansoni, S. haematobium, S. japonicum, and S. mekongi infections [56].

\section{Development and application of nucleic acid detection in the diagnosis of schistosomiasis \\ Nucleic acid detection of S. japonicum}

Among the three main species of human schistosomes, $S$. japonicum causes the most serious damages to the hosts. This species is endemic in Asia, primarily in China, the Philippines, and Indonesia [3]. Its intermediate host is Oncomelania hupensis. The latest epidemiological investigation showed that there were approximately 300,000 schistosomiasis patients in China by the end of 2012 [57]. Thus, accurate monitoring of infected snails and freshwater sources can provide timely data of the epidemic for the local human population. As shown in Table 2, a rapid PCR technique based on the
SjR2 sequence was developed [14] and used to analyze cercaria distribution and dynamic changes in mountainous areas of the Sichuan Province. No cross-reaction was observed with S. mansoni and in negative snails. A sensitive and specific real-time PCR assay targeted at SJCHGC08270 [GenBank accession no: AY812553] was developed, which enabled for the detection of minute amounts of nucleic acid (equivalent to 0.5 cercaria) in contaminated water sources [16]. No specific amplification was found for S. mansoni, S. haematobium, avian schistosomes, and organisms present in water samples of non-endemic areas, indicating the potential value of SjR2 and SJCHGC08270 detection in the monitoring of water sources in endemic areas. Recently, a highly sensitive LAMP method using the $28 \mathrm{~s}$ rDNA of $S$. japonicum was developed [9]. The detection limit was $100 \mathrm{fg}$. This approach enabled the detection of DNA from a single miracidium and snail infected with one miracidium 1 day after infection. Moreover, this approach could detect specific DNA from a group of 100 normal snails mixed with one infected snail, and could also detect schistosomal DNA in snails found negative by microscopy.

Adult worms parasitize in the host's mesenterichepatic portal vein system, and eggs deposited in the intestinal wall are discharged in stool. To date, the KatoKatz smear method is still the gold standard for the diagnosis of $S$. japonicum infection. To overcome the limitations of low sensitivity and cross-reaction in the traditional stool examination method, PCR and nested PCR methods based on the S. japonicum 5D gene (coding miracidium antigen) were simultaneously established for the first time in 1998 [58], enabling a single egg or cercaria to be detected. Studies have demonstrated that this specific method has no cross-reaction with intestinal bacteria and human genome. Later, a series of detection methods based on SjR2 repetitive retrotransposon were established, including PCR [24], real-time PCR [37], LAMP [7], and nested PCR [39]. Among these methods, LAMP's detection limit was $0.08 \mathrm{fg}$, which means it's the most sensitive, about $10^{4}$ times more so than conventional PCR (LAMP is $96 \%$ as compared with PCR, which is $60 \%$ ). Furthermore, this procedure detected $S$. japonicum DNA in rabbit sera one week after infection and 12 weeks post-treatment with praziquantel. These results demonstrate the potential application of LAMP assay in the early diagnosis of, and in the evaluation of therapy effectiveness for, $S$. japonicum infection. In another study, a real-time PCR method targeted at NADH I [51] was able to detect $S$. japonicum DNA in a sample of negative stool mixed with a single egg. No cross-reaction was observed with S. mansoni, S. haematobium, and S. bovis. This method successfully detected a low-intensity infection in 1,727 human stool samples [28] and 12 pig 
Table 2 Nucleic acid detection of schistosomes and their corresponding applications

\begin{tabular}{|c|c|c|c|c|c|}
\hline Biomarkers & Method & Sample type & Sensitivity $\%$ & Specificity \% & References \\
\hline \multicolumn{6}{|l|}{ S. japonicum } \\
\hline SjR2 (AF412221) & LAMP & human and rabbit serum & 96.7 & 100 & [7] \\
\hline SjR2 (AF412221) & $P C R$ & rabbit serum & 60 & 100 & [24] \\
\hline SjR2 (AF412221) & Real-time PCR & rabbit serum & - & - & [38] \\
\hline SjR2 (AF412221) & Nested PCR & rabbit serum & - & - & [40] \\
\hline SjCHGCS19 & Nested PCR & human and rabbit serum & 97.67 & 96.07 & [41] \\
\hline 28 s rDNA(Z46504) & LAMP & snail tissue & - & - & [14] \\
\hline $\mathrm{SjCHGC08270}$ & Real-time PCR & Water & 93 & - & [16] \\
\hline 5D gene & Nested PCR & adult worm and egg & - & - & [58] \\
\hline NADH I & Real-time PCR & human, pig, buffalo feces & - & - & {$[28,51,52]$} \\
\hline Mitochondria gene & $P C R$ & adult worm & - & - & [60] \\
\hline ITS2 & Real-time PCR & mouse feces, snail tissue & - & - & [61] \\
\hline \multicolumn{6}{|l|}{ S. mansoni } \\
\hline SM1-7 (M61098) & $P C R$ & human feces, urine, serum and mice serum & $96-100$ & 88-91.2 & {$[17,18,22,35,67,70,71]$} \\
\hline SM1-7 (M61098) & PCR & water and plankton & - & - & {$[15,65]$} \\
\hline SM1-7 (M61098) & LAMP & snail tissue & - & - & [10] \\
\hline SM1-7 (M61098) & PCR-ELISA & human feces & 97.4 & 85.1 & {$[68,69]$} \\
\hline SM1-7 (M61098) & Real-time PCR & human feces and serum & 80 & 92.4 & [8] \\
\hline Genomic DNA & Hybridization & snail tissue & - & - & [63] \\
\hline $18 \mathrm{~s} r \mathrm{rNA}$ & Nested PCR & snail tissue & - & - & [46] \\
\hline mitochondria gene & Multiplex PCR & snail tissue & - & - & {$[64,66]$} \\
\hline Satellite DNA & LAMP & mice feces and serum & - & - & [72] \\
\hline \multicolumn{6}{|l|}{ S. haematobium } \\
\hline Dra I & PCR & adult worm, snail tissue, human brain and urine & 98 & 82 & {$[12,13,20,44,73]$} \\
\hline Dra I & Real-time PCR & human serum, urine, feces & $96.6-100$ & $93.6-94.4$ & [23] \\
\hline Dra I & LAMP & snail tissue & - & - & [10] \\
\hline Sh110 & PCR & adult worm, snail tissue & - & - & [74] \\
\hline Sh73/Dra I & Multiplex PCR & adult worm, snail tissue & - & - & [45] \\
\hline $\mathrm{NADH} 3$ & PCR & snail tissue & - & - & [55] \\
\hline ITS2 (DQ677661) & PCR & human urine & - & - & {$[33,34]$} \\
\hline \multicolumn{6}{|c|}{ Differential detection methods } \\
\hline ITS2 (AF146037/8) & PCR-RFLP & adult worm and cercaria & - & - & [75] \\
\hline $\operatorname{cox} 1$ & Multiplex PCR & adult worm & - & - & [76] \\
\hline 005AAT/Dra I & PCR & adult worm & - & - & [77] \\
\hline Dra I/SM1-7 & PCR & human urine, feces & $99-100$ & $71-100$ & [17] \\
\hline $\operatorname{cox} I$ & $P C R$ & adult worm, human blood & - & - & {$[56,78]$} \\
\hline Mitochondria gene & Copro-PCR & human feces & 87.7 & 100 & [79] \\
\hline
\end{tabular}

"-": no mention or no accurate data in paper

feces [54], even immunoglobulin G antibody titers remained high in all infected groups in the latter study. This same method was also used to check previous observations based on microscopy, to determine that the Philippine buffalo was not a major reservoir host for schistosomiasis [59]. An investigation of 81 random samples of buffalo stool by different methods showed that the prevalence rate of $S$. japonicum infection was $3.7 \%$ by Kato-Katz smear, $0 \%$ by miracidia hatching, and $51.5 \%$ by real-time PCR. Therefore, it is necessary to reevaluate the role of Philippine water buffalos in the transmission of S. japonicum infection. 
Other highly specific detection methods have also been established. A specific and sensitive PCR procedure based on S. japonicum mitochondrial genes [GenBank accession no: NC-002544] was developed. Its detection limit was $0.05 \mathrm{ng}$ and it has the ability to distinguish between closely-related trematode species, such as S. mansoni, S. haematobium, Fasciola hepatica, F. gigantica, C. sinensis, and Opisthorchis viverrini [60]. Another specific PCR technique targeted at internal transcribed spacer (ITS) 2 sequence was described and applied to detect infected snails and fecal samples of mice. No cross-reaction was observed with S. mekongi, F. gigantica, O. viverrini, E. malayanum, and Paragonimus heterotremus [61].

\section{Nucleic acid detection of S. mansoni}

Schistosoma mansoni is mainly distributed in Africa, as well as in the Middle East and South America [62]. Its intermediate host is Biomphalaria. The conventional identification of snails infected with $S$. mansoni involves observing cercarial shedding under light. Alternatively, snails may be crushed between glass slides and inspected for the presence of sporocysts. However, these detection methods have limitations when there's a low parasite burden, in prepatent infections, and in concurrent infections. Fortunately, a dot hybridization method was developed to detect $S$. mansoni DNA in snails, which enabled the monitoring of early prepatent and apparent infections [63]. In 1997, a nested PCR method targeting the $18 \mathrm{~S}$ rDNA of $S$. mansoni was described by Hanelt [45]. The detection limit was $10 \mathrm{fg}$. Infected snails were detected as early as 1 day after penetration of a single miracidium. In another study, a multiplex PCR approach based on the minisatellite repeat sequence from $S$. mansoni mitochondrial DNA was developed [64], which enabled the identification of infected snails during prepatent infections. In 1998, the use of PCR amplification of S. mansoni (SM)1-7 was proposed to detect cercariae of $S$. mansoni in water [65]. This approach could detect as little as $10^{-6}$ ng of S. mansoni DNA and a single cercaria, but it was not widely used because of the PCR product's ladder pattern. In 2006, a single-step technique based on multiplex PCR assay was developed for the identification of Biomphalaria species and diagnosis of $S$. mansoni infection simultaneously [66]. Species-specific primers were directed both at ITS2 of snails and the mitochondrial DNA of S. mansoni. The methodology has been shown to be efficient, fast, and reproducible for Biomphalaria identification and diagnosis of snails infected with $S$. mansoni during the prepatent period. Recently, a LAMP assay based on the highly abundant sequence SM1-7 was established [10]. Detection limit of this assay is $0.1 \mathrm{fg}$, which is 10 times higher than that of the PCR method described above. It is possible to identify infected snails from the first day after exposure to miracidia. Test results can be directly assessed by the naked eye, indicating its potential for monitoring early infections and infections in a large number of samples.

Similar to S. japonicum, S. mansoni adults parasitize in mesenteric blood vessels, and eggs are mainly excreted through feces. Accurate detection of egg-derived DNA is helpful for the differential diagnoses of schistosomiasis. In 2002, a PCR assay was established and used to detect serum and stool specimens from patients infected with $S$. mansoni, revealing no cross-reaction with $A$. lumbricoides, A. duodenale, T. solium, and T. trichiura [22]. A sensitivity study showed that the detection limit was $1 \mathrm{fg}$ (10 times lower than that when using the Kato-Katz method). This method was successfully applied to investigate fecal samples of 194 individuals living in an endemic area [67]. The prevalence of infection was $30.9 \%$ in triplicate fecal samples examined using the Kato-Katz method, whereas it was $38.1 \%$ in a single fecal sample examined using the PCR technique. Subsequently, a technique incorporating PCR-enzyme-linked immunosorbent assay (ELISA) based on the former PCR assay was developed and used to detect infection in human fecal samples, showing the potential for estimating parasitic load and therapeutic efficacy [68, 69]. Furthermore, this method was also applied to analyze DNA from human urine samples $[17,70]$, feces $[18,71]$, and mice serum [34] by others. Recently, another LAMP method based on $S$. mansoni satellite series [GenBank accession no: L27240] was established and successfully used to detect $S$. mansoni DNA in stool samples as early as 1 week post-infection, whereas the Kato-Katz technique cannot detect eggs in feces until 6 weeks post-infection. No cross-reaction was found with S. japonicum, S. haematobium, S. intercalatum, T. taeniaeformis, E. granulosus, and other nematodes, which suggests high specificity [72]. Furthermore, Carvalho [26] applied a real-time PCR assay targeted at SM1-7 to examine human feces and serum samples. The results showed that the positive rate arrived at by using the PCR technique was higher than that obtained by the Kato-Katz method. In another study, a similar real-time PCR technique was used to test hamster feces and serum samples [8]. The first detection of $S$. mansoni eggs in feces by the Kato-Katz method and by PCR occurred 49 days post-infection. In contrast, the detection of $S$. mansoni DNA in serum using the PCR technique was detected from 14 up to 56 days postinfection, demonstrating that serum is a trustworthy source of DNA in cases of prepatent infections.

\section{Nucleic acid detection of S. haematobium}

Schistosoma haematobium is mainly distributed in Africa, the Middle East, and the Eastern Mediterranean [1]. Adult 
worms live in the host's pelvic venous plexus and bladder veins, causing urogenital schistosomiasis. The eggs can penetrate the vessel wall and migrate toward the mucosal tissue and lumen of the genitourinary tract. Some eggs are excreted in urine or genital secretions, while a substantial portion becomes trapped in tissues of urogenital organs and induces acute and chronic inflammation. Hematuria and proteinuria can be used in clinical diagnosis. The gold standard of diagnosis is microscopic detection of eggs in urine, but this method is less sensitive in cases of lowgrade infections and also it cannot detect single sex or prepatent infections. A highly sensitive PCR assay using the Dra I repetitive sequence was established, enabling the detection of single cercaria [43]. The detection limit was as little as $10 \mathrm{fg}$ of $S$. haematobium DNA. The specificity test showed that the Dra I sequence cross-reacted with S. bovis, S. magrebowiei, S. mattheei, S. curassoni, and $S$. intercalatum, but not with S. mansoni, Trichobilharzia ocellata, and Echinostoma spp.. Consequently, this method has been applied to a variety of specimens by various researchers [13, 73]. For instance, a total of 2,146 Bulinus globosus snails were examined by Allan [12]. The positive rate detected using the PCR method (40-100 \%) was consistently higher than in the evaluation of shedding cercariae $(3.96 \%)$. Similarly, 89 urine specimens from school-age children in Niger were analyzed by Ibironke [20]. The PCR method showed higher sensitivity compared to that observed in the microscopy of eggs (57.3\% versus $49.4 \%$ ).

To satisfy the demand of screening prepatent infections and low parasite loads, more sensitive methods have been established. A LAMP method based on the Dra I repeated sequence has been developed [10]. The detection limit $(0.1 \mathrm{fg})$ was 100 times more sensitive than that achieved using the PCR method described earlier [43]. It was possible to identify infection from the first day after exposure to miracidia. Later, a real-time PCR assay also based on Dra I was developed [23], which was successfully applied to detect infection in human feces, serum, and urine samples.

In addition, nucleic acid detection has an advantage in evaluating treatment efficacy. A six-month cohort study [32] was conducted to assess treatment efficacy with single-dose praziquantel $(40 \mathrm{mg} / \mathrm{kg})$, for which 33 women with $S$. haematobium infection were recruited. After treatment, eggs were not detected in the women's urine and cervical samples, however, the PCR method was able to detect schistosome DNA in eight of the women $(24 \%)$. This study suggests that single-dose praziquantel cannot completely eliminate $S$. haematobium DNA in a substantial number of patients. In another study, 390 urine specimens from 114 school-age children infected with $S$. haematobium were examined using microscopy and real-time PCR assay [33]. Daily fluctuations in microscopy diagnosis were more significant than those observed using the PCR method. Moreover, the PCR method showed higher sensitivity (92\%) when compared to microscopy (31\%), both pretreatment and post-treatment. This confirms that the real-time PCR method is an accurate and reproducible tool for monitoring treatment effectiveness.

The Bulinus species is an intermediate host of S. haematobium and other related trematode species. Moreover, the Dra I sequence cross-reacted with certain animal schistosomes, therefore a more effective tool for accurately monitoring infected snails is required. In 2007, a PCR assay targeting a repetitive sequence, $S$. haematobium (Sh)110, was developed and successfully applied to detect infection in wild snails [74]. This method enabled accurate distinction of $S$. haematobium from S. curassoni, S. intercalatum, S. bovis, and S. mattheei (but not from S. margrebowiei) through different amplification bands. Subsequently, a better multiplex PCR assay using the specific sequence $\mathrm{SH73}$ and Dra I was established and successfully applied to detect infected wild snails. It was able to differentiate $S$. haematobium from S. curassoni, S. intercalatum, S. bovis, S. mattheei, and S. margrebowiei [44]. This method may enable the accurate evaluation of infected snails where S. haematobium is coexistent with other prevalent schistosome species. Recently, a simple and efficient PCR technique based on the mitochondrial gene NADH-3 [GenBank accession no: KF834975] was described [55]. Its detection limit was shown to be $1 \mathrm{pg}$ and no cross-reactions with other related schistosomes were observed.

\section{Differential detection methods of schistosomes}

Snails are intermediate hosts of schistosomes and many other parasites. Both human and animal schistosomes may cause coinfection in certain endemic areas. Generally, an etiological method or a simple PCR method cannot distinguish between the species of Schistosoma, whereas combined detection methods can achieve this.

To date, S. mansoni, S. haematobium, and S. bovis are widespread in Africa. Bulinus is the intermediate host of the latter two schistosomes and the morphology of their cercaria is quite similar. A novel PCR-restriction fragment length polymorphism (RFLP) method based on ITS2 enabled the differentiation of S. haematobium from $S$. bovis through restrictive enzyme-digested products [75]. Similarly, an efficient multiplex PCR technique based on COX I was developed, which can distinguish S. haematobium from S. bovis [76]. In another study, a PCR assay based on Dra I sequence of $S$. haematobium and satellite sequence 005AAT of S. mansoni was described [77]. The detection limit was $10 \mathrm{fg}$. Specificity studies showed that 005AAT of S. mansoni only had a cross-reaction with $S$. rodhaini, while Dra I 
sequence had cross-reaction with many animal schistosomes, suggesting the potential limitation of Dra I in the diagnosis of schistosomiasis. Recently, a combined PCR procedure targeting Dra I and SM1-7 was established and applied to analyze 86 human samples. The sensitivity and specificity were $99-100 \%$ and $71-100 \%$, respectively. Meanwhile, results using the Kato-Katz method for S. mansoni (76 \%) and haematuria for S. haematobium $(30 \%)$ were shown to be significantly less sensitive [17].

Endemic schistosome species in Asia include S. japonicum, S. mansoni, and S. mekongi. A combined method was developed to distinguish between the four species. The universal primers and species-specific primers were designed according to COX I and the mitochondria gene, respectively. This method has been tested by analyzing serum and urine specimens of canoidea and murine [56], as well as human blood samples [78]. In the latter study, schistosome DNA was detected from all Kato-Katz-positive samples and partial Kato-Katznegative samples (9/22 serum and 10/41 urine samples). A multiplex PCR assay targeting mitochondria DNA was used to distinguish $S$. mansoni from S. japonicum [79]. Another multiplex PCR based on $28 \mathrm{~s}$ rDNA sequence [47] was able to simultaneously differentiate $S$. bovis from other human schistosomes (S. japonicum, S. mansoni, S. haematobium, S. intercalatum). This detection procedure was successfully used for human urine specimens. The sensitivity and specificity were $94.9-100 \%$ and $98.9-99.9 \%$, respectively.

\section{Conclusion}

Schistosomiasis remains one of the most prevalent parasitic infections in the world, and has significant economic and public health consequences, particularly in poor communities. The advent of large-scale mass chemotherapy campaigns for schistosomiasis in endemic countries has led to a lower intensity of infections and consequently reduced the effectiveness of conventional diagnostic tests such as serology and the Kato-Katz stool smear. However, more sensitive detection methods are needed in the clinical setting and for epidemiological studies. With the rapid development of molecular biological techniques, nucleic acid tests show potential for application in the diagnosis of infections. These methods are characterized by high sensitivity, high specificity, and rapid response. Investigators from different countries have developed a variety of nucleic acid detection methods based on various target genes. These have been demonstrated to detect parasite-derived DNA in snail tissue, monitor cercaria in contaminated water sources, provide reliable diagnostic results, evaluate drug therapeutic effects, assess host infection density, and identify early or prepatent infections. Of these methods, the highly sensitive and specific LAMP assay has already been used for amplification of other microorganisms and parasites. Unlike the PCR and real-time PCR techniques, LAMP assay does not require amplification cycles by thermocycling or amplicon detection by electrophoresis. Another advantage is that test results can be assessed by the naked eye. This suggests that the LAMP method may be useful in the detection of schistosomiasis in the field.

Generally, there are limited reports on the application of these detection methods in endemic areas. The fact is that nucleic acid tests require a well-equipped laboratory and highly trained technicians, all of which are much more costly than using etiological methods. DNA extraction is a critical step when carrying out nucleic acid tests. There are different commercial kits for extracting DNA from blood, urine, tissues, and fecal samples. Among the various biological samples, feces pose the most complex problems for DNA extraction and require new strategies to be developed. A simple and inexpensive DNA preparation method is required. It is also easy to contaminate nucleic acid amplification under unsuitable laboratory conditions, thus giving rise to falsepositive results. As the gold standard of schistosomiasis diagnosis, the Kato-Katz method has many advantages. It is convenient, rapid, cheap, and less demanding of laboratory facilities. Although a large amount of experimental data has shown that both sensitivity and specificity of nucleic acid tests are significantly higher than those of the Kato-Katz method, the nucleic acid method cannot completely replace Kato-Katz. The procedures of the nucleic acid method should be simplified and the cost should be reduced, thus enabling the development of suitable detection techniques for large-scale application in endemic areas of schistosomiasis.

\section{Additional file}

Additional file 1: Multilingual abstracts in the six official working languages of the United Nations. (PDF $238 \mathrm{~kb}$ )

\begin{abstract}
Abbreviations
COX: cyclooxygenase; DNA: deoxyribonucleic acid; ELISA: enzyme-linked immunosorbent assay; ITS: internal transcribed spacer; LAMP: loop-mediated isothermal amplification; NADH: nicotinamide adenine dinucleotide hydrogen; PCR: polymerase chain reaction; RFLP: restriction fragment length polymorphism; RNA: ribonucleic acid; SH: Schistosoma haematobium; SjR2: Schistosoma japonicum retrotransposon 2; SM: Schistosoma mansoni; WHO: World Health Organization.
\end{abstract}

\section{Competing interests}

The authors declare that they have no competing interests.

\section{Authors' contributions}

ZLV and ZW were responsible for designing, coordinating and writing the review. All authors contributed to, read, and approved the final paper. 


\section{Acknowledgments}

This work was supported by the National Major Scientific and Technologica Special Project (no. 2012ZX10004220) and the National Natural Science Foundation of China (nos. 81401688, 81271855, 81261160324, 81371836, and 81572023)

\section{Author details 712082, China. \\ Received: 10 June 2015 Accepted: 14 March 2016 \\ Published online: 30 March 2016}

'Department of Parasitology, Zhongshan School of Medicine, Sun Yat-sen University, Guangzhou 510080, China. ${ }^{2}$ Key Laboratory of Tropical Disease Control, Ministry of Education, Guangzhou 510080, China. ${ }^{3}$ Department of Pathogenic Biology, Medical School, Xizang Minzu University, Xianyang

\section{References}

1. WHO. Schistosomiasis: number of people receiving preventive chemotherapy in 2012. Wkly Epidemiol Rec. 2014;89:21-8.

2. WHO. The control of schistosomiasis. Second report of the WHO Expert Committee. World Health Organ Tech Rep Ser. 1993;830:1-86.

3. Gryseels B, Polman K, Clerinx J, Kestens L. Human schistosomiasis. Lancet. 2006:368:1106-18

4. Favre TC, Bogea TH, Rotenberg L, da Silva HS, Pieri OS. Cercarial emergence of Schistosoma mansoni from Biomphalaria glabrata and Biomphalaria straminea. Mem Inst Oswaldo Cruz. 1995;90:565-7.

5. Katz N, Chaves A, Pellegrino J. A simple device for quantitative stool thicksmear technique in Schistosomiasis mansoni. Rev Inst Med Trop Sao Paulo. 1972;14:397-400

6. Lv ZY, Wu ZD, Zhang LM, Ji PY, Cai YF, Luo SQ, Wang HX, Li H. Genome mining offers a new starting point for parasitology research. Parasitol Res. 2015;114:399-409.

7. Xu J, Rong R, Zhang HQ, Shi CJ, Zhu XQ, Xia CM. Sensitive and rapid detection of Schistosoma japonicum DNA by loop-mediated isothermal amplification (LAMP). Int J Parasitol. 2010:40:327-31.

8. Carvalho Espirito-Santo MC, Alvarado-Mora MV, Dias-Neto E, Botelho-Lima LS, Moreira JP, Amorim M, Silva Pinto PL, Heath AR, Pagliusi Castilho VL, Do Nascimento Goncalves EM, et al. Evaluation of real-time PCR assay to detect Schistosoma mansoni infections in a low endemic setting. BMC Infect Dis. 2014;14:558.

9. Kumagai T, Furushima-Shimogawara R, Ohmae $H$, Wang TP, Lu S, Chen R, Wen L, Ohta N. Detection of early and single infections of Schistosoma japonicum in the intermediate host snail, Oncomelania hupensis, by PCR and loop-mediated isothermal amplification (LAMP) assay. Am J Trop Med Hyg. 2010;83:542-8.

10. Abbasi I, King CH, Muchiri EM, Hamburger J. Detection of Schistosoma mansoni and Schistosoma haematobium DNA by loop-mediated isotherma amplification: identification of infected snails from early prepatency. Am J Trop Med Hyg. 2010;83:427-32.

11. Hamburger J, He-Na, Xin XY, Ramzy RM, Jourdane J, Ruppel A. A polymerase chain reaction assay for detecting snails infected with bilharzia parasites (Schistosoma mansoni) from very early prepatency. Am J Trop Med Hyg. 1998;59:872-6.

12. Allan F, Dunn AM, Emery AM, Stothard JR, Johnston DA, Kane RA Khamis AN, Mohammed KA, Rollinson D. Use of sentinel snails for the detection of Schistosoma haematobium transmission on Zanzibar and observations on transmission patterns. Acta Trop. 2013;128:234-40.

13. Akinwale OP, Kane RA, Rollinson D, Stothard JR, Ajayi MB, Akande DO, Ogungbemi MO, Duker C, Gyang PV, Adeleke MA. Molecular approaches to the identification of Bulinus species in south-west Nigeria and observations on natural snail infections with schistosomes. J Helminthol. 2011;85:283-93.

14. Driscoll AJ, Kyle JL, Remais J. Development of a novel PCR assay capable of detecting a single Schistosoma japonicum cercaria recovered from Oncomelania hupensis. Parasitology. 2005;131:497-500.

15. Hertel J, Kedves K, Hassan AH, Haberl B, Haas W. Detection of Schistosoma mansoni cercariae in plankton samples by PCR. Acta Trop. 2004;91:43-6

16. Hung YW, Remais J. Quantitative detection of Schistosoma japonicum cercariae in water by real-time PCR. PLoS Negl Trop Dis. 2008;2:e337.

17. Lodh N, Naples JM, Bosompem KM, Quartey J, Shiff CJ. Detection of parasite-specific DNA in urine sediment obtained by filtration differentiates between single and mixed infections of Schistosoma mansoni and S. haematobium from endemic areas in Ghana. PLoS ONE. 2014:9(3):e91144.

18. Carvalho GCD, Marques LHDS, Gomes LI, Rabello A, Ribeiro LC, Scopel KKG, Tibirica SHC, Coimbra ES, Abramo C. Polymerase chain reaction for the evaluation of Schistosoma mansoni infection in two low endemicity areas of Minas Gerais, Brazil. Mem Inst Oswaldo Cruz. 2012;107:899-902.

19. Zhou L, Liang B, Zhao YY, Huang L, Wang YF. [Fluorescent quantitative realtime PCR for detection of Schistosoma japonicum]. Zhongguo Ji Sheng Chong Xue Yu Ji Sheng Chong Bing Za Zhi. 2008;26:299-303.

20. Ibironke OA, Phillips AE, Garba A, Lamine SM, Shiff C. Diagnosis of Schistosoma haematobium by detection of specific DNA fragments from filtered urine samples. Am J Trop Med Hyg. 2011;84:998-1001.

21. Obeng BB, Aryeetey YA, de Dood CJ, Amoah AS, Larbi IA, Deelder AM, Yazdanbakhsh M, Hartgers FC, Boakye DA, Verweij JJ, et al. Application of a circulating-cathodic-antigen (CCA) strip test and real-time PCR, in comparison with microscopy, for the detection of Schistosoma haematobium in urine samples from Ghana. Ann Trop Med Parasitol. 2008;102:625-33.

22. Pontes LA, Dias-Neto E, Rabello A. Detection by polymerase chain reaction of Schistosoma mansoni DNA in human serum and feces. Am J Trop Med Hyg. 2002;66:157-62

23. Cnops L, Soentjens P, Clerinx J, Van Esbroeck M. A Schistosoma haematobiumspecific real-time PCR for diagnosis of urogenital schistosomiasis in serum samples of international travelers and migrants. PLoS Negl Trop Dis. 2013;7:e2413.

24. Xia CM, Rong R, Lu ZX, Shi CJ, Xu J, Zhang HQ, Gong W, Luo W: Schistosoma japonicum: a PCR assay for the early detection and evaluation of treatment in a rabbit model. Exp Parasitol. 2009;121:175-9.

25. Zhou L, Tang J, Zhao Y, Gong R, Lu X, Gong L, Wang Y. A highly sensitive TaqMan real-time PCR assay for early detection of Schistosoma species. Acta Trop. 2011;120:88-94.

26. Carvalho Espirito-Santo MC, Alvarado-Mora MV, Silva Pinto PL, de Brito T, Botelho-Lima L, Heath AR, Amorim MG, Dias-Neto E, Chieffi PP, Rebello Pinho JR, et al. Detection of Schistosoma mansoni infection by TaqMan (R) Real-Time PCR in a hamster model. Exp Parasitol. 2014:143:83-9.

27. Gentile R, Lessa Goncalves MM, Da Costa Neto SF, Da Costa MM, Saramago Peralta $\mathrm{RH}$, Peralta JM. Evaluation of immunological, parasitological and molecular methods for the diagnosis of Schistosoma mansoni infection before and after chemotherapy treatment with praziquantel in experimentally infected Nectomys squamipes. Vet Parasitol. 2011;180:243-9.

28. Lier T, Simonsen GS, Wang T, Lu D, Haukland HH, Vennervald BJ, Hegstad J, Johansen MV. Real-time polymerase chain reaction for detection of lowintensity Schistosoma japonicum infections in China. Am J Trop Med Hyg. 2009:81:428-32

29. Fung MS, Xiao N, Wang S, Carlton EJ. Field evaluation of a PCR test for Schistosoma japonicum egg detection in low-prevalence regions of China. Am J Trop Med Hyg. 2012;87:1053-8.

30. Aryeetey YA, Essien-Baidoo S, Larbi IA, Ahmed K, Amoah AS, Obeng BB, van Lieshout L, Yazdanbakhsh M, Boakye DA, Verweij JJ. Molecular diagnosis of Schistosoma infections in urine samples of school children in Ghana. Am J Trop Med Hyg. 2013;88:1028-31.

31. Wang C, Chen L, Yin X, Hua W, Hou M, Ji M, Yu C, Wu G. Application of DNA-based diagnostics in detection of schistosomal DNA in early infection and after drug treatment. Parasit Vectors. 2011:4:164.

32. Downs JA, Kabangila R, Verweij JJ, Jaka H, Peck RN, Kalluvya SE, Changalucha JM, Johnson WD, van Lieshout L, Fitzgerald DW. Detectable urogenital schistosome DNA and cervical abnormalities 6 months after single-dose praziquantel in women with Schistosoma haematobium infection. Tropical Med Int Health. 2013;18:1090-6.

33. Vinkeles Melchers NVS, van Dam GJ, Shaproski D, Kahama Al, Brienen EAT, Vennervald BJ, van Lieshout L. Diagnostic performance of Schistosoma real-time $P C R$ in urine samples from Kenyan children infected with Schistosoma haematobium: day-to-day variation and follow-up after praziquantel treatment. PLoS Negl Trop Dis. 2014;8:e2807.

34. Hussein HM, El-Tonsy MM, Tawfik RA, Ahmed SA-E-G. Experimental study for early diagnosis of prepatent schistosomiasis mansoni by detection of free circulating DNA in serum. Parasitol Res. 2012;111:475-8.

35. Allam AF, Kader O, Zaki A, Shehab AY, Farag HF. Assessing the marginal error in diagnosis and cure of Schistosoma mansoni in areas of low endemicity using Percoll and PCR techniques. Tropical Med Int Health. 2009;14:316-21.

36. Allam AF, Farag HF, Zaki A, Kader OA, Abdul-Ghani R, Shehab AY. Detection of low-intensity Schistosoma mansoni infection by Percoll sedimentation 
and real-time PCR techniques in a low-endemicity Egyptian setting. Tropical Med Int Health. 2015;20:658-64.

37. Guan W, Xu J, Liang S, Xia C-m. Quantifcational detection of schistosoma japonicum DNA in serum of the host and assessment of infectiosity by realtime PCR. Chinese Journal of Zoonses. 2014;30:263-7.

38. Laha T, Brindley PJ, Smout MJ, Verity CK, McManus DP, Loukas A. Reverse transcriptase activity and untranslated region sharing of a new RTE-like, non-long terminal repeat retrotransposon from the human blood fluke, Schistosoma japonicum. Int J Parasitol. 2002;32:1163-74.

39. Liu A, Yang Q, Guo J, Xu J, Xia C, 杨巧林, 郭俊杰, 许静, 夏超明. DNA detection of low-intensity Schistosoma japonicum infection by nested-PCR assay in serum of host. Suzhou University Journal of Medical Science. 2010;30:915-917,930.

40. Guo JJ, Zheng HJ, Xu J, Zhu XQ, Wang SY, Xia CM. Sensitive and specific target sequences selected from retrotransposons of Schistosoma japonicum for the diagnosis of schistosomiasis. PLoS Negl Trop Dis. 2012;6:e1579.

41. Hamburger J, Turetski T, Kapeller I, Deresiewicz R. Highly repeated short DNA sequences in the genome of Schistosoma mansoni recognized by a species-specific probe. Mol Biochem Parasitol. 1991;44:73-80.

42. Suzuki T, Osada Y, Kumagai T, Hamada A, Okuzawa E, Kanazawa T. Early detection of Schistosoma mansoni infection by touchdown PCR in a mouse model. Parasitol Int. 2006;55:213-8.

43. Hamburger J, He-Na, Abbasi I, Ramzy RM, Jourdane J, Ruppel A. Polymerase chain reaction assay based on a highly repeated sequence of Schistosoma haematobium: a potential tool for monitoring schistosome-infested water. Am J Trop Med Hyg. 2001;65:907-11.

44. Abbasi I, Hamburger J, Kariuki C, Mungai PL, Muchiri EM, King CH. Differentiating Schistosoma haematobium from related animal SchistosomeS by PCR amplifying inter-repeat sequences flanking newly selected repeated sequences. Am J Trop Med Hyg. 2012;87:1059-64.

45. Hanelt B, Adema CM, Mansour MH, Loker ES. Detection of Schistosoma mansoni in Biomphalaria using nested PCR. J Parasitol. 1997:83:387-94.

46. Chen J-h, Wen L-y, Zhang X-Z, Zhang J-f, Yu L-I, Hong L-d. [Development of a PCR assay for detecting Schistosoma japonicum-infected Oncomelania hupensis]. Zhongguo Ji Sheng Chong Xue Yu Ji Sheng Chong Bing Za Zhi. 2006:24:204-7.

47. Sandoval N, Siles-Lucas M, Perez-Arellano JL, Carranza C, Puente S, Lopez-Aban J, Muro A. A new PCR-based approach for the specific amplification of DNA from different Schistosoma species applicable to human urine samples. Parasitology. 2006;133:581-7.

48. Sandoval N, Siles-Lucas M, Aban JL, Perez-Arellano JL, Garate T, Muro A. Schistosoma mansoni: a diagnostic approach to detect acute schistosomiasis infection in a murine model by PCR. Exp Parasitol. 2006;1 14:84-8.

49. Do Vale Gomes AL, Melo FL, Werkhauser RP, Abath FGC. Development of a real time polymerase chain reaction for quantitation of Schistosoma mansoni DNA. Mem Inst Oswaldo Cruz. 2006;1011:133-6.

50. Tong Q-B, Chen R, Zhang Y, Yang G-J, Kumagai T, Furushima-Shimogawara $R$, Lou D, Yang K, Wen L-Y, Lu S-H, et al. A new surveillance and response tool: risk map of infected Oncomelania hupensis detected by Loop-mediated isothermal amplification (LAMP) from pooled samples. Acta Trop. 2015;141:170-7.

51. Lier T, Simonsen GS, Haaheim H, O Hjelmevoll S, Vennervald BJ, Johansen MV. Novel real-time PCR for detection of Schistosoma japonicum in stool. Southeast Asian J Trop Med Public Health. 2006;37:257-64.

52. Real-time PCR Demonstrates High Prevalence of Schistosoma japonicum in the Philippines: Implications for Surveillance and Control [http://gateway. isiknowledge.com/gateway/Gateway.cgi?GWersion=2\&SrcAuth=Aegean Software\&SrcApp=NoteExpress\&DestLinkType=FullRecord\&DestApp=WOS\& KeyUT $=000349318100056]$.

53. Gordon CA, McManus DP, Acosta LP, Olveda RM, Williams GM, Ross AG, Gray DJ, Gobert GN. Multiplex real-time PCR monitoring of intestinal helminths in humans reveals widespread polyparasitism in Northern Samar, the Philippines. Int J Parasitol. 2015;45:477-83.

54. Lier T, Johansen MV, Hjelmevoll SO, Vennervald BJ, Simonsen GS. Real-time PCR for detection of low intensity Schistosoma japonicum infections in a pig model. Acta Trop. 2008;105:74-80.

55. Akinwale OP, Hock TT, Chia-Kwung F, Zheng Q, Haimo S, Ezeh C, Gyang PV. Differentiating Schistosoma haematobium from Schistosoma magrebowiei and other closely related schistosomes by polymerase chain reaction amplification of a species specific mitochondrial gene. Trop Parasitol. 2014:4:38-42.
56. Kato-Hayashi N, Kirinoki M, Iwamura Y, Kanazawa T, Kitikoon V, Matsuda H, Chigusa Y. Identification and differentiation of human schistosomes by polymerase chain reaction. Exp Parasitol. 2010;124:325-9.

57. Wu W, Feng AC, Huang YX. Research and control of advanced schistosomiasis japonica in China. Parasitol Res. 2015;1 14:17-27.

58. Chen Y, Weng X, Xu Z. [Experimental study on detection of Schistosoma japonicum 5D gene by using PCR]. Zhongguo Ji Sheng Chong Xue Yu Ji Sheng Chong Bing Za Zhi. 1998;16:58-61.

59. Wu H-W, Qin Y-F, Chu K, Meng R, Liu Y, McGarvey ST, Olveda R, Acosta L, Ji M-J, Fernandez T, et al. High prevalence of Schistosoma japonicum infection in Water Buffaloes in the Philippines assessed by real-time polymerase chain reaction. Am J Trop Med Hyg. 2010;82:646-52.

60. Zhao G-H, Li J, Song H-Q, Li X-Y, Chen F, Lin R-Q, Yuan Z-G, Weng Y-B, Hu M, Zou F-C, Zhu X-Q. A specific PCR assay for the identification and differentiation of Schistosoma japonicum geographical isolates in mainland China based on analysis of mitochondrial genome sequences. Infect Genet Evol. 2012;12:1027-36.

61. Thanchomnang T, Intapan P, Sri-Aroon P, Lulitanond V, Janwan P, Sanpool O, Maleewong W. Molecular detection of Schistosoma japonicum in infected snails and mouse faeces using a real-time PCR assay with FRET hybridisation probes. Mem Inst Oswaldo Cruz. 2011;106:831-6.

62. Colley DG, Bustinduy AL, Secor E, King CH. Human schistosomiasis. Lancet. 2014;383:2253-64.

63. Hamburger J, Weil M, Pollack Y. Detection of Schistosoma mansoni DNA in extracts of whole individual snails by dot hybridization. Parasitol Res. 1987;74:97-100

64. Jannotti-Passos LK, Vidigal THDA, Dias-Neto E, Pena SDJ, Simpson AJG, Dutra WO, Souza CP, Carvalho-Parra JF. PCR amplification of the mitochondrial DNA minisatellite region to detect Schistosoma mansoni infected in Biomphalaria glabrata snails. J Parasitol. 1997;83:395-9.

65. Hamburger J, Xu Y-X, Ramzy RM, Jourdane J, Ruppel A. Development and laboratory evaluation of a polymerase chain reaction for monitoring Schistosoma mansoni infestation of water. Am J Trop Med Hyg. 1998:59:468-73

66. Jannotti-Passos LK, Magalhaes KG, Carvalho OS, Vidigal T. Multiplex PCR for both identification of Brazilian Biomphalaria species (Gastropoda : Planorbidae) and diagnosis of infection by Schistosoma mansoni (Trematoda : Schistosomatidae). J Parasitol. 2006;92:401-3.

67. Pontes LA, Oliveira MC, Katz N, Dias-Neto E, Rabello A. Comparison of a polymerase chain reaction and the Kato-Katz technique for diagnosing infection with Schistosoma mansoni. Am J Trop Med Hyg. 2003;68:652-6.

68. Vidal Siqueira LM, Gomes LI, Oliveira E, de Oliveira ER, de Oliveira AA, Enk MJ, Carneiro NF, Rabello A, Zech Coelho PM. Evaluation of parasitological and molecular techniques for the diagnosis and assessment of cure of schistosomiasis mansoni in a low transmission area. Mem Inst Oswaldo Cruz. 2015;110:209-14.

69. Gomes LI, Dos Santos Marques LH, Enk MJ, de Oliveira MC, Coelho PM, Rabello A. Development and evaluation of a sensitive PCR-ELISA system for detection of schistosoma infection in feces. PLoS Negl Trop Dis. 2010;4:e664.

70. Enk MJ, Oliveira E, Silva G, Rodrigues NB. Diagnostic accuracy and applicability of a PCR system for the detection of Schistosoma mansoni DNA in human urine samples from an endemic area. PLoS ONE. 2012;7(6):e38947.

71. Carneiro TR, Saramago Peralta RH, Cunha Pinheiro MC, de Oliveira SM, Peralta JM, Moraes Bezerra FS. A conventional polymerase chain reactionbased method for the diagnosis of human schistosomiasis in stool samples from individuals in a low-endemicity area. Mem Inst Oswaldo Cruz. 2013;108:1037-44.

72. Fernandez-Soto P, Gandasegui Arahuetes J, Sanchez Hernandez A, Lopez Aban J, Vicente Santiago B, Muro A. A Loop-Mediated Isothermal Amplification (LAMP) assay for early detection of Schistosoma mansoni in stool samples: a diagnostic approach in a murine model. Plos Neglected Tropical Diseases. 2014;8(9):e3126.

73. Imai K, Koibuchi T, Kumagai T, Maeda T, Osada Y, Ohta N, Koga M, Nakamura H, Miura T, Iwamoto A, Fujii T. Cerebral schistosomiasis due to Schistosoma haematobium confirmed by PCR analysis of brain specimen. J Clin Microbiol. 2011;49:3703-6.

74. Abbasi I, King CH, Sturrock RF, Kariuki C, Muchiri E, Hamburger J. Differentiation of Schistosoma haematobium from related schistosomes by PCR amplifying an inter-repeat sequence. Am J Trop Med Hyg. 2007;76:950-5. 
75. Barber KE, Mkoji GM, Loker ES. PCR-RFLP analysis of the ITS2 region to identify Schistosoma haematobium and S-bovis from Kenya. Am J Trop Med Hyg. 2000;62:434-40.

76. Webster BL, Rollinson D, Stothard JR, Huyse T. Rapid diagnostic multiplex PCR (RD-PCR) to discriminate Schistosoma haematobium and S. bovis. J Helminthol. 2010;84:107-14.

77. Akinwale OP, Laurent T, Mertens P, Leclipteux T, Rollinson D, Kane R, Emery A, Ajayi MB, Akande DO, Fesobi TW. Detection of schistosomes polymerase chain reaction amplified DNA by oligochromatographic dipstick. Mol Biochem Parasitol. 2008;160:167-70.

78. Kato-Hayashi N, Leonardo LR, Arevalo NL, Tagum MNB, Apin J, Agsolid LM, Chua JC, Villacorte EA, Kirinoki M, Kikuchi M, et al. Detection of active schistosome infection by cell-free circulating DNA of Schistosoma japonicum in highly endemic areas in Sorsogon Province, the Philippines. Acta Trop. 2015:141:178-83.

79. Gobert GN, Chai M, Duke M, McManus DP. Copro-PCR based detection of Schistosoma eggs using mitochondrial DNA markers. Mol Cell Probes. 2005;19:250-4.

Submit your next manuscript to BioMed Central and we will help you at every step:

- We accept pre-submission inquiries

- Our selector tool helps you to find the most relevant journal

- We provide round the clock customer support

- Convenient online submission

- Thorough peer review

- Inclusion in PubMed and all major indexing services

- Maximum visibility for your research

Submit your manuscript at www.biomedcentral.com/submit
Biomed Central 